$1-1-1959$

\title{
Farming, farm people, and farm expansion in Fayette, Raleigh, and Summers counties, West Virginia, 1958
}

\author{
William H. Metzler
}

W.W. Armentrout

Follow this and additional works at: https://researchrepository.wvu.edu/ wv_agricultural_and_forestry_experiment_station_bulletins

\section{Digital Commons Citation}

Metzler, William H. and Armentrout, W. W., "Farming, farm people, and farm expansion in Fayette, Raleigh, and Summers counties, West Virginia, 1958" (1959). West Virginia Agricultural and Forestry Experiment Station Bulletins. 439.

https://researchrepository.wvu.edu/wv_agricultural_and_forestry_experiment_station_bulletins/416 @ WVU. It has been accepted for inclusion in West Virginia Agricultural and Forestry Experiment Station Bulletins by an authorized administrator of The Research Repository @ WVU. For more information, please contact ian.harmon@mail.wvu.edu. 
Digitized by the Internet Archive in 2010 with funding from Lyrasis Members and Sloan Foundation 


\section{BULLETIN 439}

December 1959

FARMING, FARM PEOPLE,

and FARM EXPANSION

In Fayette, Raleigh, and Summers Counties,

West Virginia, 1958

WEST VIRGINIA UNIVERSITY AGRICULTURAL EXPERIMENT STATION 


\section{THE AUTHORS}

Authors of Farming, Farm People, and Farm Expansion in Fayette, Raleigh, and Summers Counties, West Virginia, 1958, are William H. Metzler and W. W. Armentrout. Mr. Metzler is Agricultural Economist, Agricultural Research Division, Agricultural Research Service, United States Department of Agriculture. Dr. Armentrout is Professor and Head of Agricultural Economics and Rural Sociology in the College of Agriculture, Forestry, and Home Economics and Agricultural Economist in the West Virginia University Agricultural Experiment Station.

IVEST VIRGINiA UNIVERSITY

Agricultural Experiment Station

College of Agriculture, Forfistry, and Hone Economics

A. H. VanLandingham, Director

MORGantown 


\section{Farming, Farm People, and Farm}

\section{Expansion in Fayette, Raleigh, and Summers Counties, West Virginia, 1958}

WILLIAM H. METZLER and W. W. ARMENTROUT

THE purpose of this report is to give some insight into the farming situation, attitudes of the farm people, and possibilities for increasing farm income in the Fayette, Raleigh, and Summers county area of West Virginia. Agriculture is important in the economy of an area even though relatively few of the area's people are engaged in it. If income from agriculture, or any other industry, could be increased, the total income in the area would be increased by an amount several times the size of the original increased income. The original increase in income is passed from one service industry to another before it is all taken out of circulation through savings. It is the industries which bring outside dollars into the community which are most important in establishing the amount of business that will be transacted within the community.

Some of the basic data in regard to the agriculture of Fayette, Raleigh, and Summers counties are presented here. They were obtained in a special survey made for the Area Rural Development Committee in May 1958. They represent the findings from a random sample-297 farms in the 3-county area.

Table 1. Sources of Income of Sample Households Living on Farms, Fayette, Raleigh, and Suminers Counties, 1958

\begin{tabular}{|c|c|c|}
\hline ITEM & NUMBER & PERCENT \\
\hline All farms tn survey & \multirow{4}{*}{$\begin{array}{r}297 \\
41\end{array}$} & \multirow[t]{2}{*}{100} \\
\hline Farm households with & & \\
\hline all income from farming .................. & & 14 \\
\hline Major source of income from & & 10 \\
\hline $\begin{array}{l}\text { Agriculture a minor source of } \\
\text { income }\end{array}$ & 207 & 70 \\
\hline
\end{tabular}

Only 14 percent of the families living on farms in the 3-county area obtain all their income from agriculture (Table 1). Nonfarm work is, for most of the others, the major source of income but they do some farming on the side. They may do farming to supplement their regular incomes, or it may be that they simply like farming. 
This means also that many of our farms have become chiefly residences for nonfarm people. It may mean that the soil resources are not always used to the best advantage.

Those who live by farming alone are close to the bottom of the incone scale (Table 2). Only a few had net incomes of more than $\$ 2,000$ per year. Of those families with the two sources of income-agriculture and nonfarm work-approximately half had total incomes of more than $\$ 5,000$. Those families with incomes from pensions, social security, unemployment compensation, and similar "nonwork" sources, in addition to agriculture, usually came within the income bracket of $\$ 1,000$ to $\$ 3,000$.

Tabie 2. Source and Size of Incomes of Fambies Living on Sample Farms, Fayette, Raleigh, and Sumuers Counties, 1958

\begin{tabular}{|c|c|c|c|c|c|c|c|c|}
\hline \multirow[b]{2}{*}{$\begin{array}{l}\text { SOURCE } \\
\text { OF } \\
\text { INCOME }\end{array}$} & \multirow{2}{*}{$\begin{array}{l}\text { ALL } \\
\text { FARMIERS } \\
\text { REPORT- } \\
\text { ING }\end{array}$} & \multicolumn{7}{|c|}{ Families With Ixconie } \\
\hline & & $\begin{array}{c}\text { CXDER } \\
\$ 500\end{array}$ & $\begin{array}{l}\$ 500 \\
\text { To } \\
\$ 599\end{array}$ & $\begin{array}{l}\$ 1,000 \\
\text { To } \\
\$ 1,999\end{array}$ & $\begin{array}{l}\$ 2,000 \\
\text { то } \\
\$ 2,999\end{array}$ & $\begin{array}{l}\$ 3,000 \\
\text { To } \\
\$ 3.999\end{array}$ & $\begin{array}{l}\$ 4,000 \\
\text { To } \\
\$ 4,999\end{array}$ & $\begin{array}{l}\$ 5,000 \\
\text { AND } \\
\text { OVER }\end{array}$ \\
\hline All families & $\begin{array}{c}\text { Number } \\
297\end{array}$ & $\begin{array}{c}\text { Number } \\
19\end{array}$ & $\begin{array}{c}\text { Number } \\
26\end{array}$ & $\begin{array}{c}\text { Number } \\
52\end{array}$ & $\begin{array}{c}\text { Number } \\
55\end{array}$ & $\begin{array}{c}\text { Number } \\
36\end{array}$ & $\begin{array}{c}\text { Number } \\
29\end{array}$ & $\begin{array}{c}\text { Number } \\
80\end{array}$ \\
\hline $\begin{array}{l}\text { Income from } \\
\text { agriclture } \\
\text { only }\end{array}$ & 41 & 15 & 13 & 11 & 2 & - & - & - \\
\hline $\begin{array}{l}\text { Agriculture } \\
\text { plus nonfarm } \\
\text { work }\end{array}$ & 85 & - & - & 7 & 10 & 13 & 13 & 42 \\
\hline $\begin{array}{l}\text { Agriculture } \\
\text { plus nonwork } \\
\text { Agriculture, } \\
\text { nonfarm work, } \\
\text { and nonwork }\end{array}$ & s3 & 3 & 12 & 28 & 28 & 16 & 15 & 34 \\
\hline
\end{tabular}

A third of the farms in the three comties are less than 30 acres in size (Table 3). Usually they have investments ranging from $\$ 2,000$ to $\$ 2,500$ in land and fam buildings. Another third are from 30 to 100 acres in size but do not have an equivalent increase in the size of investment. The proportion of the land in crops in the latter is smaller than in the former, but there is a marked increase in acreages of pastureland and woodland. Farms containing more than 100 acres tend still further in the direction of pasture and woodland.

Nost farms in the area are also small in terms of the total amount of work clone on them (Table 4). In 1957, on half the farms, this was less than 50 days. Only 10 percent were large enough to occupy the full time of a worker.

Note that the income figures here are for net income from the farm and do not include income from other work clone by the farmer or by 


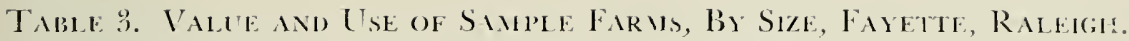
A.no Summers Counties, 1958

\begin{tabular}{|c|c|c|c|c|c|c|}
\hline \multirow[b]{2}{*}{$\begin{array}{c}\text { FARM SIZE } \\
\text { (ACRES) }\end{array}$} & \multirow[b]{2}{*}{$\begin{array}{l}\text { NUMBER OF } \\
\text { FARMS IN } \\
\text { SAMPLE }\end{array}$} & \multirow{2}{*}{$\begin{array}{c}\text { PERCENTAGE } \\
\text { OF ALL } \\
\text { FARMS }\end{array}$} & \multirow{2}{*}{$\begin{array}{c}\text { AVERAGE VALUE } \\
\text { OF LAND AND } \\
\text { BUILDINGS } \\
\text { PER FARM** }\end{array}$} & \multicolumn{3}{|c|}{ ATE?AGE NUMBEr of ACRES IN* } \\
\hline & & & & Crops & $\begin{array}{c}\text { Opex } \\
\text { PermaNent } \\
\text { Pastere }\end{array}$ & WOODLAXD \\
\hline All farms ............ & 297 & 100 & $\begin{array}{c}\text { Dollars } \\
3,138\end{array}$ & 13 & 34 & 37 \\
\hline Under 10 & 50 & 17 & 2,100 & 4 & 2 & 1 \\
\hline 10 to $29 \ldots$ & 54 & 18 & 2.378 & 5 & 6 & 4 \\
\hline 30 to $49 \ldots$ & 33 & 11 & 3,847 & 8 & 16 & 14 \\
\hline 50 to 69 & 36 & 12 & 2,269 & 11 & 21 & 22 \\
\hline to to 99 & 36 & 12 & 2,678 & 14 & 24 & 38 \\
\hline 100 to 139 . & 38 & 13 & 3,321 & 17 & 46 & 45 \\
\hline 140 to 219 & 30 & 10 & 3,823 & 20 & 62 & 77 \\
\hline 220 and over. & 20 & $\tau$ & 7,639 & 42 & 196 & 205 \\
\hline
\end{tabular}

Does not cover an average of 4 acres per farm that were devoted to other uses, for example, building areas, garden space, roads, and so on.

*:Excludes value of dwelling.

Table 4. Net Income of Farmers on Samiple Farms Related to Total Days of Work, Fayette, Raleigh, and Summers Counties, 1957

\begin{tabular}{|c|c|c|c|c|c|c|}
\hline \multirow{2}{*}{$\begin{array}{c}\text { TOTAL NET FARM } \\
\text { INCOME } \\
\text { (DOLLARS) }\end{array}$} & \multirow{2}{*}{$\begin{array}{c}\text { ALL } \\
\text { FARMERS } \\
\text { REPORT- } \\
\text { ING }\end{array}$} & \multicolumn{5}{|c|}{ TCt L Number of Days of Work on the Farm* } \\
\hline & & $\begin{array}{l}\text { UNDER } \\
50\end{array}$ & $\begin{array}{c}50 \text { то } \\
99\end{array}$ & $\begin{array}{c}100 \mathrm{TO} \\
149\end{array}$ & $\begin{array}{c}150 \text { and } \\
\text { OVER }\end{array}$ & $\begin{array}{c}\text { AVErage NUMBer } \\
\text { DAYS OF WORK }\end{array}$ \\
\hline Minus income .... & $\begin{array}{c}\text { Number } \\
33\end{array}$ & 19 & 5 & 5 & 4 & 50.7 \\
\hline$\$ \quad 0$ to $249 \ldots$ & 30 & 26 & 4 & 0 & 0 & 26.3 \\
\hline 250 to 499 & 28 & 21 & 5 & 1 & 1 & 35.4 \\
\hline 500 to 749 & 43 & 28 & 13 & 1 & 1 & 48.2 \\
\hline 750 to $999 \ldots$ & 43 & 17 & 20 & 4 & 2 & 65.6 \\
\hline 1,000 to $1,499 \ldots$ & 68 & 30 & 23 & 12 & 3 & 66.8 \\
\hline 1,500 to 1,999 & 31 & 8 & 7 & $T$ & 9 & 121.8 \\
\hline 2,000 and over ..... & 21 & 3 & 5 & 2 & 11 & 165.0 \\
\hline Total & 297 & 152 & 82 & 32 & 31 & 78.9 \\
\hline
\end{tabular}

*Calculated in terms of total number of days of productive work required.

members of his family. More than half received less than $\$ 1,000$ from their farming operations in 1957, but neither did they do any large amount of farm work.

Operators who lost monev despite a large amount of work were usually beginners who were putting out money in order to build up their business.

The major source of income lrom farms in the area in 1957 was from the sale of livestock and livestock products (Table 5). Sales of broilers and other poultry accounted for almost half of the income from agriculture, $\$ 164,604$. Sales of cattle were next in importance. Dairying 
Table 5. Total Sales From 297 Sample Farms, Fayette, Raleigh, and Summers Counties, 1957

\begin{tabular}{|c|c|c|c|}
\hline ITEM SOLD & $\begin{array}{l}\text { VALUES OF SALES } \\
\text { (DOLLARS) }\end{array}$ & $\begin{array}{c}\text { PERcentage } \\
\text { OF } \\
\text { Total SALEs }\end{array}$ & $\begin{array}{c}\text { PERCENTAGE } \\
\text { OF } \\
\text { Livestock } \\
\text { SALES }\end{array}$ \\
\hline Livestock & 260,853 & 72 & 100 \\
\hline Poultry & 164,604 & - & 63 \\
\hline Cattle & 74,860 & - & 29 \\
\hline Hogs & 6,078 & - & 2 \\
\hline Sheep & 13,313 & - & 5 \\
\hline Milk and Cream ............. & 34,616 & 10 & - \\
\hline Eggs & 23,439 & 6 & - \\
\hline Crops & 23,790 & 6 & - \\
\hline Timber & 9,522 & 3 & - \\
\hline Wool & 2,357 & 1 & - \\
\hline Other & 3,081 & 2 & - \\
\hline Total & 359,544 & 100 & - \\
\hline
\end{tabular}

is on the increase in this area and now accounts for about 10 percent of the farm income. Sales of eggs are also important. In 1957 they brought about as much income to the area as sales of all crops-grain, feed, fruit, vegetables.

Total sales averaged $\$ 1,200$ per farm.

Approximately three-fourths of the farmers in the area have dairy cattle (Table 6). Approximately three-fourths have poultry. These, then, make up the stable backbone of the agriculture in the area. Some hogs, however, were raised on more than half of the farms. Only one-fourth had beef cattle.

The highest return both per farm and in total was from poultry.

Table 6. Number, Vaidue, and Sales of Livestock on Sample Farms, Fayette, Raleigh, and Summers Counties, 1957

\begin{tabular}{|c|c|c|c|c|c|c|c|}
\hline TYPE OF LIVESTOCK & $\begin{array}{r}\text { NuI } \\
\text { AND PEI } \\
\text { OF } \mathrm{F}\end{array}$ & $\begin{array}{l}\text { IBER } \\
\text { CENTAGE } \\
\text { ARMS }\end{array}$ & $\begin{array}{c}\text { TOTAL } \\
\text { FARMS } \\
\text { REPORTED }\end{array}$ & $\begin{array}{c}\text { AVERAGE } \\
\text { NuMber } \\
\text { PER } \\
\text { FARM }\end{array}$ & $\begin{array}{c}\text { Total } \\
\text { VALUE } \\
\text { of } \\
\text { SALES }\end{array}$ & $\begin{array}{c}\text { PERCENT- } \\
\text { AGE OF } \\
\text { Total } \\
\text { Sales }\end{array}$ & $\begin{array}{c}\text { AVERAGE } \\
\text { VALUE OF } \\
\text { SALES } \\
\text { PER FARM }\end{array}$ \\
\hline Total farms & $\begin{array}{c}\text { Number } \\
297\end{array}$ & $\begin{array}{c}\text { Percent } \\
100\end{array}$ & Number & - & $\begin{array}{l}\text { Dollars } \\
260,049\end{array}$ & 100 & $\begin{array}{c}\text { Dollars } \\
876\end{array}$ \\
\hline Farms with - - & & & & & & & \\
\hline Dairy cattle & 214 & 72 & 1,146 & 5 & 38,488 & 15 & 180 \\
\hline Beef cattle ......... & 73 & 25 & 932 & 13 & 36,372 & 14 & 498 \\
\hline Hogs .................. & 163 & 55 & 613 & 4 & 6,078 & 2 & 37 \\
\hline Sheep & 37 & 12 & 1,709 & 46 & 13,313 & 5 & 360 \\
\hline Poultry & 227 & 76 & 181,739 & 801. & $164,60 t$ & 63 & 725 \\
\hline Workstock & 127 & 43 & 188 & 1 & 1,194 & 1 & 9 \\
\hline Other livestock & 25 & 8 & - & - & - & 一 & - \\
\hline
\end{tabular}


Sales of crops are a minor source of income to farmers in the area (Table 7 ). Although many produce hay or grain for use on the fam, the amount sold is not important. Corn comes nearest to an exception. Some corn was produced on almost half of the farms, and sales of corn averaged $\$ 125$ per farm.

One-third of the farms produced some fruit, but sales of fruit averaged only $\$ 62$. One-fifth of the farms produced some commercial vegetables. Sales of vegetables a veraged about $\$ 200$ per farm.

The biggest expense to farmers in the area is for the purchase of feed and hay for poultry and livestock (Table 8 ). A reduction in this cost might be possible through home production of feed: or purchases from local producers might be expanded.

Table 7. Acreage and Sales of Major Crops on Sample Farms, Fayette, Raleigh, and Sumaiers Countifs, 1957

\begin{tabular}{|c|c|c|c|c|c|c|}
\hline Crop & $\begin{array}{c}\text { TOTAL } \\
\text { FARMERS } \\
\text { REPORTING }\end{array}$ & $\begin{array}{l}\text { PERCENT- } \\
\text { AGE OF } \\
\text { FARMERS }\end{array}$ & $\begin{array}{c}\text { TOtAL } \\
\text { ACRE- } \\
\text { AGE IN } \\
\text { Crop }\end{array}$ & $\begin{array}{c}\text { AVERAGE } \\
\text { ACREAGE } \\
\text { PER } \\
\text { FARM }\end{array}$ & $\begin{array}{c}\text { AvERAGE } \\
\text { VALUE } \\
\text { OF SALES } \\
\text { PER } \\
\text { FARM* }\end{array}$ & $\begin{array}{c}\text { AvERAGE } \\
\text { RETURN } \\
\text { PER } \\
\text { ACRE }\end{array}$ \\
\hline All farms & $\begin{array}{c}\text { Number } \\
297\end{array}$ & 100 & - & - & $\begin{array}{c}\text { Dollars } \\
\text { S2 }\end{array}$ & Dollars \\
\hline Corn & 142 & 48 & 443 & 3 & 125 & 40 \\
\hline Small grains for grain & 56 & 19 & 382 & $\tau$ & 43 & 6 \\
\hline Small grains for hay .... & 57 & 19 & 257 & 4 & 53 & 12 \\
\hline Alfalfa & 50 & 17 & 339 & 7 & 53 & 8 \\
\hline Other hay & 181 & 61 & 1923 & 11 & $10 \mathrm{~s}$ & 10 \\
\hline Fruit, orchard & 105 & 35 & 183 & 2 & 62 & 36 \\
\hline Fruit, small & 35 & 12 & 44 & 1 & 79 & 63 \\
\hline Vegetables ..... & 58 & 20 & 98 & 2 & 199 & 118 \\
\hline
\end{tabular}

*Only 289 farms reported any sales, so this average per farm is based on those farms that had sales.

Table 8. Farm Expenses on Sample Farmis, Fayette, Raleigh, Summers Counties, 1957

\begin{tabular}{|c|c|c|c|c|c|c|}
\hline ITEM & $\begin{array}{l}\text { NuI } \\
\text { AND PEI } \\
\text { ALL }\end{array}$ & $\begin{array}{l}\text { BER } \\
\text { CENTAGE } \\
\text { ARMS }\end{array}$ & $\begin{array}{c}\text { Total } \\
\text { Expense }\end{array}$ & $\begin{array}{c}\text { PERCENT- } \\
\text { AGE OF } \\
\text { TOTAL } \\
\text { EXPENSE }\end{array}$ & $\left|\begin{array}{c}\text { Average } \\
\text { Expense } \\
\text { Per Farm } \\
\text { RePorting }\end{array}\right|$ & $\begin{array}{c}\text { AVERAGE } \\
\text { EXPENSE } \\
\text { ALI. } \\
\text { FARMS }\end{array}$ \\
\hline All farms & $\begin{array}{c}\text { Number } \\
297\end{array}$ & $\begin{array}{c}\text { Percent } \\
100\end{array}$ & $\begin{array}{l}\text { Dollars } \\
213,366\end{array}$ & 100 & $\begin{array}{c}\text { Dollars } \\
718\end{array}$ & $\begin{array}{c}\text { Dollars } \\
718\end{array}$ \\
\hline Fertilizer and lime & 269 & 91 & 17,283 & $s$ & 64 & $5 s$ \\
\hline ()ther crop expenses & 283 & 95 & 12,427 & 6 & 44 & +2 \\
\hline 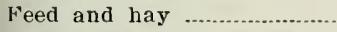 & 236 & 79 & 102,823 & ts & 436 & 346 \\
\hline Other livestock expenses .... & 123 & 41 & 4,419 & 2 & 36 & 15 \\
\hline $\begin{array}{l}\text { Hired labor, custom work, } \\
\text { repair work } \\
\text { Other expenses }\end{array}$ & $\begin{array}{r}232 \\
69\end{array}$ & $\begin{array}{l}78 \\
23\end{array}$ & $\begin{array}{r}72,622 \\
3,792\end{array}$ & $\begin{array}{r}34 \\
2\end{array}$ & $\begin{array}{r}313 \\
55\end{array}$ & $\begin{array}{r}244 \\
13\end{array}$ \\
\hline
\end{tabular}


Farmers in the area do not always use the most up-to-date methods (Table 9). This is as likely to be due to inadequate finances as to lack of interest. Greater use of the most productive methods should bring larger amounts of money into the community.

Table 9. Extent to Which Farmers on Sample Farmis Were Using New Farm Practices, Fayette, Raleigh, Summers Counties, 1957

\begin{tabular}{|c|c|c|}
\hline FARM PRACTice & $\begin{array}{c}\text { NUMBER OF FARMERS } \\
\text { REPORTING }\end{array}$ & $\begin{array}{l}\text { PERCentage of } \\
\text { ALL Farmers }\end{array}$ \\
\hline 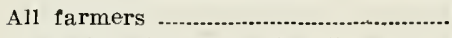 & 297 & 100 \\
\hline Had soil tested during last 5 years .... & 142 & 48 \\
\hline $\begin{array}{l}\text { Applied lime to cropland during } \\
\text { last } 5 \text { years }\end{array}$ & \multirow{2}{*}{147} & \multirow[t]{2}{*}{49} \\
\hline $\begin{array}{l}\text { Applied lime to pasture during } \\
\text { last } 5 \text { years }\end{array}$ & & \\
\hline Fertilized pasture during last & 109 & 37 \\
\hline $\begin{array}{l}3 \text { years } \\
\text { Made changes in fertilizer program }\end{array}$ & 111 & 37 \\
\hline 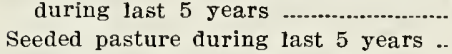 & $\begin{array}{l}66 \\
96\end{array}$ & $\begin{array}{r}22 \\
3\end{array}$ \\
\hline Mow or clip pasture each year ........... & 124 & 42 \\
\hline $\begin{array}{l}\text { Wrade changes in crops grown } \\
\text { during last } 5 \text { years }\end{array}$ & \multirow[t]{2}{*}{81} & 27 \\
\hline $\begin{array}{l}\text { Made changes in insect control } \\
\text { during last } 5 \text { years }\end{array}$ & & 29 \\
\hline $\begin{array}{l}\text { Made changes in feeding livestock } \\
\text { during last } 5 \text { years }\end{array}$ & 85 & \multirow[t]{2}{*}{15} \\
\hline $\begin{array}{l}\text { Made changes in controlling livestock } \\
\text { during last } 5 \text { years }\end{array}$ & 46 & \\
\hline
\end{tabular}

Only the farmers under 50 years of age were asked whether they would like to expand or change their farm business. Almost half of then said they would like to do so (Table 10). One in eight would like to expand his livestock operations. An equal number would like to clear or improve additional land. Others would like to add to their machinery or equipment, or expand their fertilizer program.

Most of those wanting to make these changes were part-time and subsistence farmers. Most of them stated that they had difficulty in making the changes because of lack of capital.

The reason most frequently given by farmers for lack of interest in increasing income from farming was that they had other employment or were not interested in faming. Two other reasons were important also: (1) satisfaction with the farm at its present size; and, (2) the idea that farming was not profitable and there was no use in expanding operations.

Farms in the area are not highly mechanized (Table 11). More than half operate with horse-drawn equipment. Hay is still harvested by oldfashioned methods. Few of the farmers who keep dairy cattle have milking machines. 
Table 10. Attitudes of Farmers on Sample Farms in Regard to Increasing Size of Farm Business, Fayette, Raleigh, Summers Counties, 1958

\begin{tabular}{|c|c|c|c|c|}
\hline ITEM & $\begin{array}{l}\text { ALL } \\
\text { FARMERS } \\
\text { REPORTING }\end{array}$ & $\begin{array}{l}\text { PERCENT- } \\
\text { AGE OF } \\
\text { ALL } \\
\text { FARMERS }\end{array}$ & $\begin{array}{c}\text { ALL.. } \\
\text { COMMERCIAL } \\
\text { FARMERS } \\
\text { REPORTING }\end{array}$ & $\begin{array}{c}\text { OTHER } \\
\text { FARMERS } \\
\text { REPORTING }\end{array}$ \\
\hline & Number & & Number & Number \\
\hline Type of Changes & & & & \\
\hline $\begin{array}{l}\text { All farmers under } 50 \text { years old } \\
\text { All farmers wishing to make }\end{array}$ & 118 & 100 & 28 & 90 \\
\hline changes & 50 & 42 & 10 & 40 \\
\hline $\begin{array}{l}\text { Increase livestock enterprise } . . . \\
\text { Change to more fruits and }\end{array}$ & 14 & 12 & 5 & 9 \\
\hline vegetables .................................. & 3 & 3 & 1 & 2 \\
\hline Land-clearing, fences, ponds, etc. & 14 & 12 & 2 & 12 \\
\hline Add machinery and equipment & 10 & 8 & 2 & 8 \\
\hline Use more fertilizer & 6 & 5 & - & 6 \\
\hline $\begin{array}{l}\text { Farmers with obstacles to making } \\
\text { changes }\end{array}$ & 48 & - & - & 一 \\
\hline Lack of money & 39 & 33 & 8 & 31 \\
\hline 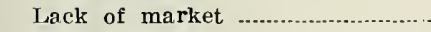 & 6 & 5 & - & 6 \\
\hline Lack of time & 3 & 3 & 2 & 1 \\
\hline $\begin{array}{l}\text { Farmers who do not desire to make } \\
\text { changes }\end{array}$ & 68 & 58 & 18 & 50 \\
\hline $\begin{array}{l}\text { Reasons for not making changes: } \\
\text { Other employment or lack of } \\
\text { interest in farming }\end{array}$ & 36 & 30 & 5 & 31 \\
\hline Satisfied with present farm & 11 & 9 & 6 & 5 \\
\hline $\begin{array}{l}\text { No money or lack of profit in } \\
\text { farming }\end{array}$ & 8 & 7 & 2 & 6 \\
\hline Poor soil or location & 4. & 3 & 3 & 1 \\
\hline Illness & 3 & 3 & 1 & 2 \\
\hline Labor not availahle & 2 & 2 & 1 & 1 \\
\hline
\end{tabular}

\section{Table 11. Type of Farm Equipuent on Sample Farms By Type of Farm, Fayette, Raleigh, Summers Counties, 1958}

\begin{tabular}{|c|c|c|c|c|c|c|}
\hline \multirow{2}{*}{ FQUIPMENT } & \multicolumn{6}{|c|}{$\begin{array}{c}\text { Number and Percentage of Farms With Specifieid } \\
\text { Equipment }\end{array}$} \\
\hline & \multicolumn{2}{|c|}{ ALL FARMS } & \multicolumn{2}{|c|}{$\begin{array}{l}\text { COMMERCLAL } \\
\text { FARMS }\end{array}$} & \multicolumn{2}{|c|}{ OTHER FARMS } \\
\hline & Number & Percent & Number & Percent & Number & Percent \\
\hline 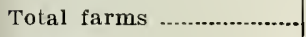 & 297 & $10 n$ & 78 & 100 & 219 & 100 \\
\hline Tractor & 101 & 34 & 39 & 50 & 62 & 28 \\
\hline Truck & 146 & 49 & 50 & 64 & 96 & 44 \\
\hline $\begin{array}{l}\text { Automobile used in } \\
\text { farm business }\end{array}$ & 97 & 33 & 34 & 44 & 63 & 29 \\
\hline Picknp balers & 13 & 4 & 8 & 10 & 5 & 2 \\
\hline Milking machines ........... & 4 & 1 & 3 & 4 & 1 & * \\
\hline Horse-drawn equipment & 161 & 54 & 39 & 50 & 123 & 56 \\
\hline
\end{tabular}

*Less than 0.5 percent. 


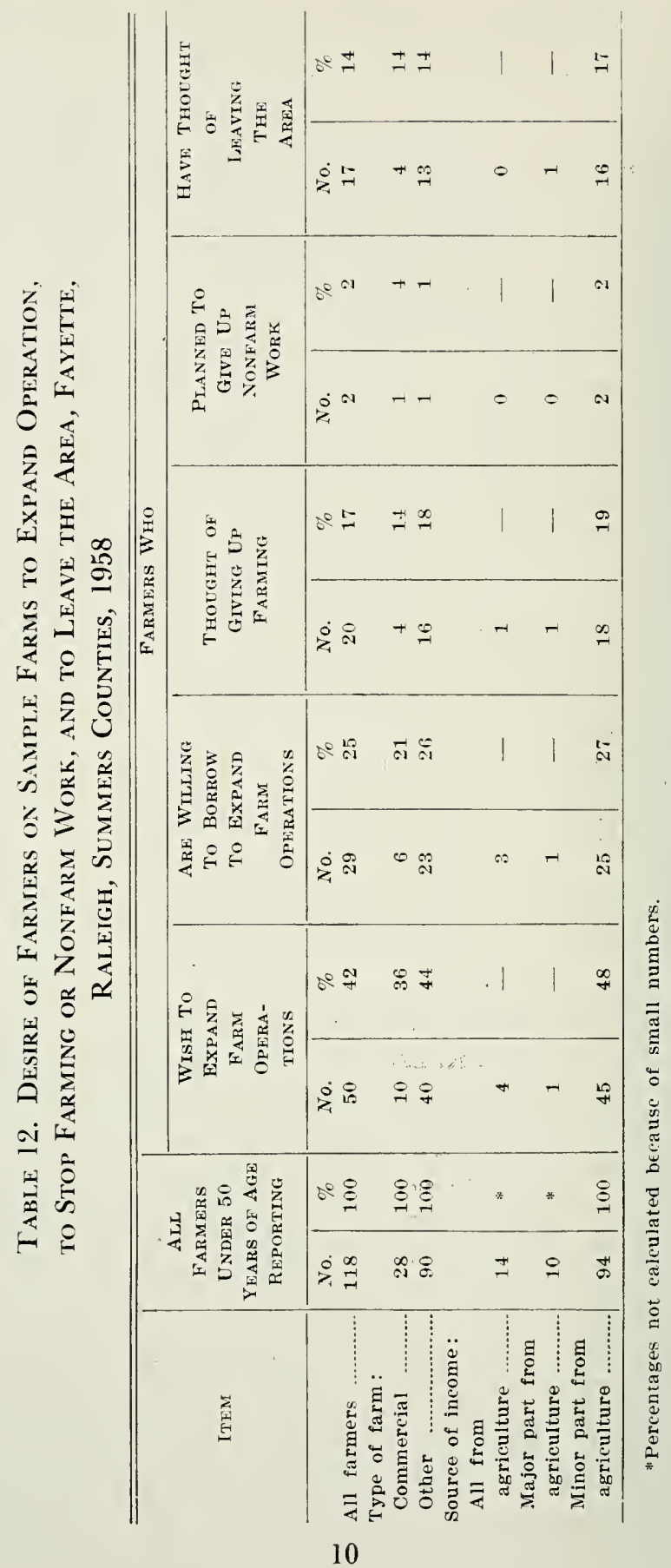


This may reflect lack of capital, or it may indicate that existing farms are too small to permit their operators to farm with the highest degree of efficiency.

Many of the larmers under 50 years of age who were interested in expanding their farm operations were willing to borrow money in order to do so (Table 12). These people were largely those who had additional source of income.

Lack of ability to obtain capital to expand existing farm operations is one of the major problems in the area. When farmers wish to expand their operations and bring more money into the community, how can. the community help them get the necessary capital?

Most of the farm homes in the area have electricity, refrigerators, and power washing machines (Table 13). Three-fourths of them have television sets, and one-third have deep-freeze units.

Although the farmers are most alert to the advantages of electricity, they lack some other modern conveniences. Approximately half have running water in the house, and half have telephones. Only a third have flush toilets, and a fourth have central heating.

\section{What These Figures Mean}

These are only a few of the findings of the 1958 survey of farms and farm people in these three counties. A more complete analysis will be presented in a later report. It will indicate that many farm and nonfarm people are not fully employed. They constitute unused resources that might be bringing more income and spending power to themselves and to the community.

Although the return per hour of work is much less in farming than

Table 13. Household Equipment of Farm Families on Sample Farms, Fayette, Raleigh, Summers Counties, 1958

\begin{tabular}{|c|c|c|}
\hline ITEM & $\begin{array}{c}\text { NUMBER OF FAMILIES } \\
\text { REPORTING }\end{array}$ & $\begin{array}{c}\text { PERCENTAGE OF FAMILIES } \\
\text { REPORTING }\end{array}$ \\
\hline 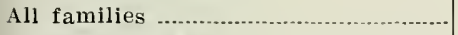 & 297 & 100 \\
\hline Electric lights & 296 & 99 \\
\hline Water in house & 166 & 56 \\
\hline Refrigerator & 289 & 97 \\
\hline 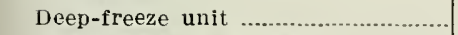 & 103 & 35 \\
\hline Power washing machine ................... & 285 & 96 \\
\hline Television set & 217 & 73 \\
\hline Automobile or truck & 211 & 71 \\
\hline Flush toilet & 107 & 36 \\
\hline Central heating & 79 & 27 \\
\hline Telephone & 139 & 47 \\
\hline Daily newspaper & 172 & 58 \\
\hline
\end{tabular}


in most occupations in the area, two important aspects concerning farming in the area must be considered: (1) The $\$ 2,500,000$ in agricultural sales mean several times that amount in the total economy; and, (2) the equally important fact that our larms are primarily homes for people who like to live in the country, although their major income is from some other source.

Both for them and for the community, income from farming is inportant. This can be increased by such measures as the following: (I) more credit available for farm development; (2) more careful selection of crops adlapted to the area; (3) greater use by farm operators of the iatest farm practices; and, (1) more complete use of all the good soil resources that are available in the area.

The trend in agriculture is toward greater specialization in the crops and products that can be produced to the greatest advantage. For West Virginia, these are grade $\mathrm{C}$ milk, eggs, broilers, and turkeys. The area is best adapted to a grassland economy, and production trends in the State indicate that specialization here is proceeding in that direction.

The major problem in the 3-county area does not involve agriculture directly. It stems from the decrease in labor required for mining coal. Agriculture will be umable to provide employment for all these additional people. The situation calls for both local industrial expansion and increased efficiency in the use of other resources in the area.

The 1958 survey indicates that the area has a large amount of labor that is not fully utilized. It indicates also that a large amount of local capital exists and that there are many residents with managerial experience and ability. What is lacking is a community plan that will utilize all these resources in such a way as to build the economy the area needs and should have. 

